\title{
THE EFFECT OF A DIRECT ELECTRIC CURRENT ON NORMAL AND ANTIBODY- SENSITIZED RED CELLS
}

\author{
BY \\ K. GOLDSMITH AND J. G. HUMBLE \\ From the John Burford Carlill Pathological Laboratories, Westminster Hospital \\ School of Medicine, London
}

(RECEIVED FOR PUBLICATION OCTOBER 25, 1950)

During experiments on the effect of direct electric currents on red cells suspended in saline an unexpected phenomenon was observed. Normal red cells showed agglutination and lysis, but if the red cells had been sensitized by antibodies there was a marked difference in the degree of agglutination and lysis. Samples of red cells which had been treated with " blocking" Rhesus antibody (anti-D and anti-CD), of the cells of an infant suffering from erythroblastosis foetalis, and also of the cells of a case of atypical haemolytic anaemia (Boorman, Dodd, and Loutit, 1946) were included in the investigations and gave similar results.

\section{Apparatus and Material}

The cell used for the electrolysis consisted of a plastic ("perspex") slide, in the centre of which was cut a circle of $12 \mathrm{~mm}$. diameter and $4 \mathrm{~mm}$. in depth. Into this were inserted two platinum wire electrodes, the ends of which were $5 \mathrm{~mm}$. apart (Fig. 1). The wire was 0.02 S.W.G.

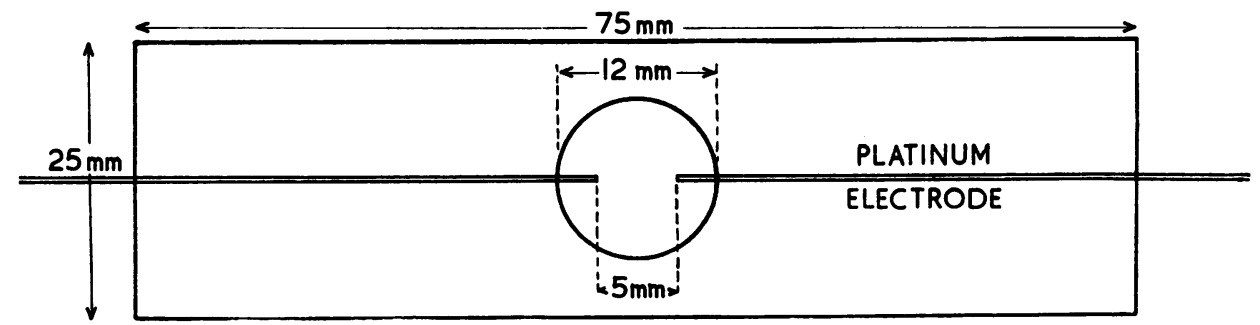

FIG. 1.-Line drawing of electric cell.

The cell was always completely filled with fluid when in use. A simple electrical circuit, incorporating a milliammeter and a variable resistance of $10,000 \mathrm{ohms}$ in series with a $4 \frac{1}{2}$-volt high capacity dry battery (three Ever Ready dry cells high E.M.F.), was used.

Recently drawn red cells were used either from capillary blood suspended in saline or from Wintrobe oxalate vials. 


\section{Methods}

Blood, $0.25 \mathrm{ml}$,, was suspended in $5 \mathrm{ml}$. of isotonic saline and washed three times. (In our experiments it was found that albumin inhibited the reaction.) After the third washing sufficient saline was added to give a suspension of approximately 10,000 to 20,000 cells per c.mm. The suspension so obtained was examined qualitatively or quantitatively.

Qualitative Examination.-Part of the suspension so prepared was placed in the electric cell and a current of 1 milliamp passed through it for three minutes. Following this a small amount of the suspension was removed by means of a Pasteur pipette and examined microscopically on a slide for the presence or absence of agglutination. Under these circumstances agglutination of normal red cells was readily seen.

Quantitative Examination.-Part of the suspension prepared as above was put into a counting chamber and the number of cells per unit volume estimated. At the same time a further sample of the suspension was put into the electric cell and a current of 1 milliamp was passed through it for three minutes. After this time had expired the current was switched off and the number of cells remaining neither agglutinated nor lysed were counted. The percentage of free cells could thus be estimated on a quantitative basis.

\section{Results}

Qualitative.-Twenty-five specimens of normal blood all underwent agglutination after three minutes.

Twenty experiments performed on normal red cells "blocked" in vitro all showed inhibition of agglutination and of lysis.

Twenty observations were made using the red cell of a newborn baby suffering from haemolytic disease of the newborn. On each occasion agglutination and haemolysis were inhibited.

Thirty experiments were made using the red cells of a case of mild atypical haemolytic anaemia. Again agglutination and haemolysis were inhibited.

Ten experiments were performed on sheep cells sensitized by rabbit anti-sheep haemolytic amboceptor. Agglutination and haemolysis were inhibited when compared with non-sensitized sheep cells.

Quantitative.-These results are presented in Table I.

TABLE I

The Quantitative Estimation of the Agglutination and Haemolysis of the Red Cells

\begin{tabular}{ll|c|c|c|c|c}
\hline \multicolumn{1}{c|}{ Nature of Cells } & $\begin{array}{c}\text { Number } \\
\text { of } \\
\text { Experiments }\end{array}$ & $\begin{array}{c}\text { Range of } \\
\text { Free Cells } \\
(\%)\end{array}$ & $\begin{array}{c}\text { Mean } \\
\text { of Free } \\
\text { Cells (\%) }\end{array}$ & $\begin{array}{c}\text { Standard } \\
\text { Deviation }\end{array}$ & $\begin{array}{c}\text { Value } \\
\text { of } \mathrm{t}\end{array}$ \\
\hline Normal clls bilocked in vitro & $\cdots$ & 25 & $30-53$ & 45.0 & 6.6 & - \\
Normal cells & 20 & $55-81$ & 60.0 & 7.5 & 7.02 \\
Erythroblastosis foetalis & $\cdots$ & 20 & $55-83$ & 63.7 & 8.4 & 8.5 \\
Atypical haemolytic anaemia & $\cdots$ & 20 & $55-78$ & 63.2 & 5.8 & 9.3 \\
\hline
\end{tabular}

On comparing the normal figures with each of the abnormal groups of results, a significant result for $t$ was obtained. It will be seen from Table $I$ that in 85 


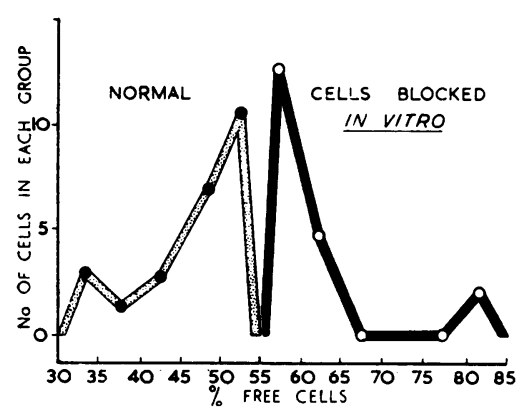

Fig. 2

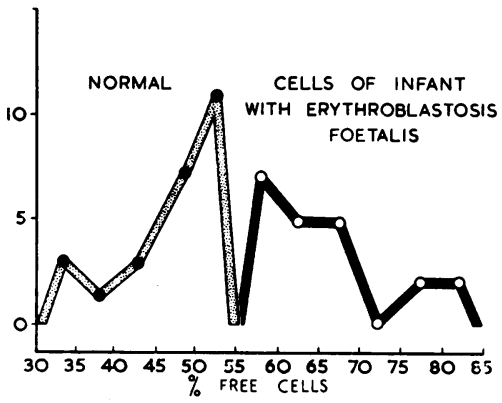

FIG. 3

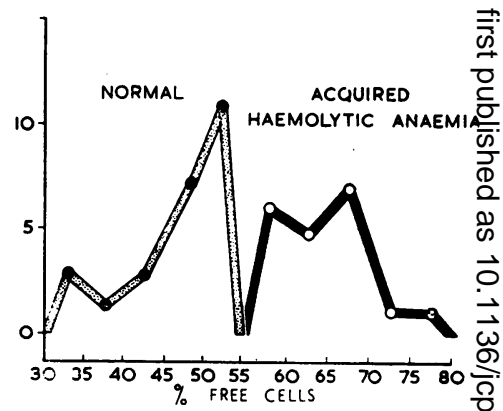

Fig. 4

Graphs to show the distribution of free cells arranged in groups of $5 \%$.

paired estimations the percentage value of "free cells" was never more than 53 . The percentage of free cells in the case of "blocked" cells was never less than 55 . These results are shown graphically in Figs. 2, 3, and 4.

\section{Discussion}

Only two references in the literature have been found which deal with the effect of direct electric currents causing agglutination and lysis of red cells, and one of these, that of Petropavlovskiy (1935) is not available in this country. Its title "Electrolysis of Erythrocytes: Effect of Constant Current on Agglutination and Haemolysis of Horse's Erythrocytes" makes it clear that the author interested himself in this problem. The second (Mori, 1935) is written in Japanese, and there is a short author's summary in English, from which it is clear that he observed lysis of normal red cells in saline. Coombs and Race (1945) studied the electrophoretic mobility of red cells in a capillary tube through which a direct electric current was passing. They noted that the mobility of the cells was decreased if they had been previously treated with either "saline" or "albumin" Rhesus antibody. They made no report of agglutination or lysis of the cells. Mori suggested in his paper that the lysis resulted from the formation of alkali produced in the neighbourhood of the negative pole. In experiments performed on bacteria (Mudd, 1934 ; Abramson, Moyer, and Gorin, 1942) it was found that when organisms were suspended in an electrophoretic cell they migrated to one of the poles, but the addition of protein inhibited this movement. The fact that agglutination of red blood cells occurs in the presence of a direct electrical current is not easy to explain. It seems likely, however, that the coating of antibody known to be present on the outside of a sensitized red cell causes the inhibition of agglutination that we noticed in our experiments. It would appear that the method described is a delicate test for the presence of agents modifying the surface of red blood cells.

\section{Summary}

A method is described for the investigation of the effect of a direct electric current on red cells in saline.

Agglutination and lysis were observed. Partial inhibition of these phenomena occurred when sensitized red cells were used. 
The fact that albumin inhibited the process suggested that protein on the outside of the erythrocytes caused some change in their response.

The method was found to give markedly abnormal findings in a case of atypical haemolytic anaemia that showed at times only a weakly positive Coombs reaction.

We would like to thank Professor R. J. V. Pulvertaft for the very helpful advice and criticism he has given us.

\section{REFERENCES}

Abramson, H. A., Moyer, L. S., and Gorin, M. H. (1942). Electrophoresis of Proteins and the Chemistry of Cell Surfaces, p. 196, New York.

Boorman, K. E., Dodd, B. E., and Loutit, J. F. (1946). Lancet, 1, 812.

Coombs, R. R. A., and Race, R. R. (1945). Nature, Lond., 156, 233.

Mori, N. (1935). J. Okayama med. Soc., 47, 1063. (In Japanese. Summary in English.)

Mudd, S. (1934). J. Immunol., 26, 447.

Petropavlovskiy, V. (1935). Fiziol. Zhur., 18, 983. Not available. 